\title{
TOS Pacific Basin Meeting
}

\author{
By Melbourne G. Briscoe
}

T HE TOS PACIFIC BASIN MEETING in Honolulu. Hawaii. July 18-22, 1994. was an experiment. It was the first meeting TOS has held that was intended to focus on a specific scientific topic. It was arranged differently, through conveners for each of the sub-themes. and was overtly intended to be small (250-300 attendees) so that focus and discussion would be maximized. An important part of the experiment was that the meeting had some concurrent sessions, instead of the traditional TOS format of plenary sessions plus poster sessions.

The Pacific Basin theme. centered on TOGA. WOCE. JGOFS. and RIDGE. was selected as an interdisciplinary and timely focus: the WOCE work in the Pacific is nearly completed. the TOGA program is almost over. JGOFS has had some major Pacific work. and RIDGE has entered a new era of exploration with submersibles and acoustics.

As another notable departure from previous meetings, it included overt sessions on policy: as meeting chairman Eric Hartwig said in his opening remarks. "The meeting is an experiment in focus. and an experiment in looking at public policy. We, the scientific community, are honest brokers for the policy makers. . . . The public is reexamining its belief in our science enterprise. Can science and technology improve our way of life?."

As this report will show. the experiment was basically quite successful: the meeting was not perfect. but it was good. and the participants seemed pleased. This report will also show that the meeting suggested a future for oceanography that is not inevitably rosy, and a challenge for

Melbourne G. Briscoe. TOS Secretary. Natimal Oceanic and Atmospheric Administration. Silver Spring. Maryland. oceanographers to do a better job of educating the public about the importance of oceanography to society.

The total attendance at the meeting was 275, of which 33 were students. Thirty-nine of the attendees were from outside the U.S. (Japan. Australia. New Caledonia. Canada. New Zealand. Taiwan. Western Samoa, and Russia). Typical attendance at a TOS biennial meeting is now 700. so the Pacific Basin meeting was smaller and more focused than previous TOS meetings.

\section{Random Highlights}

Jim Murray. in his introduction to JGOFS. commented. "JGOFS is a component of IGBP. which doesn't mean anything to most of us. . " It is a lamentable observation that the International Geosphere-Biosphere Program (IGBP). which is a major. global initiative of the International Council of Scientific Unions (ICSU) is not, in fact, better known to U.S. oceanographers. (TOS intends to provide information in Oceanography Magazine in the future about international organizations and programs and their value to the science community.)

John Delaney. in his introduction to RIDGE, observed that submarine volcanic heat input is only $1 c_{i c}$ of solar heat input. but (1) it is localized. (2) it is coming in at the bottom of a stably stratified fluid instead of at the top. and (3) it is episodic, all suggesting a potential marked effect on the ocean. In a glimpse of the excitement that is not always apparent in the large programs, he remarked. "RIDGE was developed with a passion as strong as the concepts were vague." He pointed out that every eruption has produced a vast outpouring of bacterial material-thermophiles and hyperthermophiles. arguably producing as much biomass on the bottom of the ocean in rocks. as on the surface of the planet. "A Deep Biosphere."

The TOGA presentations provided some interesting comments and insights. Tony Busalacchi remarked that TOGA induced cultural changes in the community that had worked with it for a decade. such that modeling and prediction and observations had become integrated for the ocean as never before. Mike McPhaden observed that the TOGA Tropical AtmosphereOcean (TAO) array of moorings in the equatorial Pacific provides a context for shorter. more intensive. process experiments. The array provides platforms of opportunity for various tests and experiments. In a precursor to the growth of Global Observing Systems (GCOS for climate and GOOS for the ocean I. he noted there is a feedback from process experiments to the monitoring programs. He sees transitions of parts of the post-TOGA observing system to operations. under GCOS and GOOS. McPhaden also commented on the "remarkable" agreement within $4 \mathrm{~cm}$ RMS of the Topex/Poseidon sea surface topography with the TAO dynamic heights (relative to $0-500 \mathrm{~m}$ ). Ed Sarachik. in his presentation on SeasonalInterannual Predictions. wryly concluded that. "We are getting good at predicting the 82-83 El Nino." And Bob Knox wrapped up the TOGA sessions with an eloquent plea, ". . . for the continuation of what TOGA has wrought."

Jim Broadus* introduced the Policy talks by reminding us that almost $\$ 1$ billion has been spent on acid rain studies. with almost no impact on policy. He gave us some hope. though. in saying that there have been. in fact. some lessons learned from the large programs:

\footnotetext{
${ }^{x}$ Jim died recently while snorkeling. a lasi un us
} all and to his family. He will be mised. 
a. ASSESSMENT is an important part of large programs. What does the science agree on. what are the disputes. and what are the implications of the agreements and the disputes?

b. BENEFIT-COST studies are needed.

c. COMMUNICATIONS are needed. to explain in lay terms what the science is about. Most taxpayers are looking for results that will affect their lives in a positive way.

The TOS-ONR Walter Munk Award was given to David Farmer from the Institute for Oceanographic Sciences in Sidney. British Columbia. Walter gave the citation. and summarized David's many accomplishments in the use of acoustics to describe and understand the ocean. on scales from microstructure to ocean basins. Walter said, "Dave has run (SCOR) Working Group 96 with discipline, humor, and imagination." TOS President Margaret Leinen summed up the Award ceremony in her closing words to Farmer: "We thank you for the distinction that you bring to our field."

\section{Questionnaire}

We asked the meeting participants to tell us what they thought of the TOS Pacific Basin meeting. Fifty-seven responses were received from an evaluation questionnaire distributed to the attendees at the meeting. The questions related to the format of the meeting (interdisciplinary, focused, concurrent sessions), the topics (including policy talks), and the site and costs.

The support was overwhelming for the focused yet interdisciplinary nature of the meeting. with the responses indicating that new ideas and collaborations were stimulated by the format. and that the exposure to the varying topics will be useful for the work of the participants. Some of the topics suggested for possible future focused meetings were the coastal zone and coastal-open ocean connections, airsea interactions. polar oceanography. paleoceanography. the Indian ocean tafter the 1995 intensive work there). climate prediction and wbersational needs. biological-physical coupling. and "controvervies in marine research."

There was lew support for the concurremt short talks. Which were unlike the
TOS Biennial Meeting format of plenary sessions plus poster sessions. Never-theless. 58 percent of the responses liked the concurrent sessions for the special focus meeting. as opposed to more plenary sessions. Three responses suggested mitigating the inevitable conflicts resulting from concurrent sessions by giving a talk and having a poster.

The policy talks were well received but the concept needs work. The meeting was international. but the talks were U.S.-centric. Many responses suggested orienting the policy talks more to panel discussions than to presentations, and to hear more from policymakers, and resource managers. There was clear support for continuing the inclusion of policy issues in TOS meetings, especially the topic of how science can affect policy.

The most common write-in comment in the responses was about the quality of the talks and the graphics. The TOS meetings have had a modest reputation as meetings where one could expect to hear an excellent talk. given well. on time. and with visible. informative graphics. The responses indicated that not all the talks in Honolulu met these demanding criteria. One reason TOS has tried to push for quality presentations and graphics has been to set an example for the many students in attendance. The role model of a traditional AGU talk (some call it an hour talk delivered in 12 minutes. with illegible vugraphs made the night before) has not been a role model that TOS has wished to encourage. Conveners of TOS meeting segments have routinely been instructed to try and get the speakers to recognize the value of a good talk with good graphics. but not all speakers (nor all conveners!) are responsire to the request. We need to do hetter. as a society and as speakers. Even the most compelling vientific result can be obucured by a poor presentation.

Hawaii was affirmed as the right site for a Pacific Basin meeting. esen though it is an expensive place to have such a meeting. One revponse suggested a "resort schedule" where one worked in the evening instead of the afternoon. Since I never got to the heach. I think this is a great uggevtion!

\section{Sea Changes}

There was something quite different about the TOS Pacific Basin meeting. and it came from the younger attendees. the students and new scientists. The difference showed up strongly in the questions asked after talks. especially after the policy talks. One of the questioners was C.J. Beegle, a graduate student from the University of Washington. The TOS Council asked her after the meeting to summarize some of her thoughts and perspective: they are in the accompanying box. What C.J. has to say has a clear U.S. flavor-it is based on her experience and context - but speaks to all of us and raises questions that know no national boundaries.

This TOS meeting was an experiment. As in all good experiments, you learn some things, and you develop some more questions to ask. We learned from the Honolulu meeting that a medium size. focussed scientific meeting that is interdisciplinary and international fills a niche in the spectrum of meeting types. and we learned that the TOS membership supports this kind of meeting. We learned that science-policy is a topic of interest to oceanographers, especially the younger generation. We learned that the questions asked by that generation are the crux of the "grand challenge" for us all: will our field of oceanography step up to the increasing demands of our society, and the increasing requirement that we become an active part of educating the public to the value of science and oceanography"? Or will we "wallow in nostalgia" as one critic has put it. and argue that it is not our job?

The TOS Council has discussed these questions and concerns. and is committed to leading the way in public education about the value of our enterprise. We encourage the ocean community-young and old-to step up to the grand challenge. The community is individuals. institutions. organizations. and government agencies: all must respond to the needs of society and to the education of society. Our future depends upon our efforts: we cannot risk waiting for someone else to do it. J 